\title{
A genetic variant of the NAMPT gene rs4730153 as a risk factor for the metabolic syndrome in younger age: a single-centre pilot study in Yogyakarta, Indonesia
}

\author{
Anggelia Puspasari ${ }^{1,2^{*}}$ D, Pramudji Hastuti ${ }^{1}$, Ahmad Hamim Sadewa ${ }^{1}$, Rosdiana Mus ${ }^{1,3}$, Citra Maharani ${ }^{1,2}$ and \\ Ika Setyawati ${ }^{4}$
}

\begin{abstract}
Background: The genetic variation of nicotinamide phosphoribosyl transferase (NAMPT) gene rs4730153 is reported to be associated with cardiometabolic risk, but the results are inconsistent between populations. Ethnicity, metabolic risk and lifestyle play a role in the association of the genetic variant and the metabolic syndrome (MetS). To the best of our knowledge, no research has yet been published concerning the Javanese population, so this study aimed to investigate the association of rs4730153 with MetS and its interaction with metabolic risk and lifestyle.

Results: The GG genotype ( $p=0.031$; OR 95\% Cl 3.88 [1.13-13.33]), GA+GG genotype ( $p=0.048$; OR 95\% Cl 10.52 [1.02-108.01]) and $\mathrm{G}$ allele carrier ( $p=0.006$; OR 95\% Cl 4.19 [1.51-11.64]) of rs4730153 had a higher risk of the MetS after adjusting for obesity, hypercholesterolemia, smoking and food intake. The risk was statistically significant for the younger age group $\leq 45$ years old.

Conclusion: The GG, GA+GG genotype and G allele carrier of rs4730153 have a higher risk of the MetS, especially those who are obese, hypercholesterolemic and smokers and have a higher food intake in those aged $\leq 45$ years old. Further larger, multicentre studies are required to confirm these pilot results.
\end{abstract}

Keywords: Genetic variant, Metabolic syndrome, rs4730153, NAMPT

\section{Background}

The prevalence of metabolic syndrome (MetS) continues to increase worldwide, including in Indonesia [1], and is associated with increased mortality and morbidity rates caused by cardiovascular diseases $[2,3]$. MetS is a multifactorial disease influenced by interactions between genetic variations, lifestyle and other factors, with genetic variation estimated to contribute more than $20 \%$ to the MetS phenotype. Genetic variation mapping has

\footnotetext{
* Correspondence: Anggelia.puspasari@unja.ac.id

'Department of Biochemistry, Faculty of Medicine, Public Health and

Nursing, Universitas Gadjah Mada, Yogyakarta, Indonesia

${ }^{2}$ Department of Medical Biology and Biochemistry, Faculty of Medicine and

Health Sciences, Universitas Jambi, Jambi, Indonesia

Full list of author information is available at the end of the article
}

recently gained attention for disease pathophysiology and interventions $[2,4]$.

Chronic inflammation processes are involved in MetS pathophysiology, including the increased release of proinflammatory cytokines especially from white adipose tissue (WAT) [2]. Visfatin encoded by the NAMPT gene is a pro-inflammatory cytokine mainly released from WAT and has an important role in lipid metabolism, carbohydrate metabolism, adipocyte plasticity and endothelial dysfunction and is immunomodulatory [5]. A meta-analysis reported that plasma Visfatin levels are associated with MetS, diabetes mellitus, atherosclerosis and other metabolic abnormalities [6].

A single nucleotide polymorphism (SNP) located in the intronic region gene can alter protein function and 
level, although the functional study of NAMPT genetic variant rs4730153 has not been fully elucidated. An epidemiology study in Saudi Arabia reported that the genotype variant $N A M P T$ gene rs4730153 is associated with plasma Visfatin, with subjects with GG and GA genotypes having higher plasma Visfatin than the AA genotype [7].

A previous study reported that the genetic variant of rs4730153 is associated with cardiometabolic risk. A genotype-phenotype association study related to cardiometabolic risk in Spain showed that the AA genotype has a protective effect on cardiovascular risk [8]. Furthermore, in Chinese obese children, the GG genotype has a protective effect against abnormality markers of lipid and glucose metabolism [9]. The two studies reported different protective alleles and both of them focused on genotype and phenotype association but did not analyse any other modifying factors. Therefore, this pilot study investigated the association of rs4730153 with MetS and its interaction with other modifying factors (metabolic risk and lifestyle) in a Javanese living in Yogyakarta, Indonesia.

\section{Methods}

\section{Study design and subject recruitment}

A case-control study of 168 Javanese subjects aged 2066 years living in the Yogyakarta region was conducted, with the case and control subjects carefully matched by gender and age. The population was screened to identify MetS patients in Yogyakarta, Indonesia, in 2018-2019. The inclusion criteria of this study were Javanese, aged 20-66 years old, living at Yogyakarta region at least for 5 years. Pregnant women and subjects with signs of active infection and history of cancer and taking antihypertension, lipid-lowering and antidiabetic agents regularly for at least 3 months were excluded from this study. Subjects with at least three criteria of a MetS diagnosis based on the National Cholesterol Education ProgramAdult Panel Treatment (NCEP-ATP) III criteria modification for an Asian population were selected as the case group and the others were the control group.

All study participants provided written informed consent. The study protocol was according to the Declaration of Helsinki and was approved by our institution Medical and Health Research Ethics Committee (approval number KE/0621/05/2018).

\section{Anthropometric, blood pressure, metabolic parameters and food intake measurement}

Waist circumference was measured with a standard tape measure with an anatomical marker mid-circumference between the lowest rib and anterior superior iliac spine. Central obesity was defined as waist circumference $\geq 90$ $\mathrm{cm}$ for men and $\geq 80 \mathrm{~cm}$ for women. Subjects with a body mass index (BMI) higher than $30 \mathrm{~kg} / \mathrm{m}^{2}$ were classified as obese. Systolic and diastolic blood pressures were measured twice in a seated position after $5 \mathrm{~min}$ of rest using a calibrated sphygmomanometer. Blood peripheral samples $(5 \mathrm{~mL})$ were obtained from the antecubital vein after $8 \mathrm{~h}$ of fasting. Subjects with a systolic blood pressure $\geq 130 \mathrm{mmHg}$ and/or diastolic blood pressure $\geq 85 \mathrm{mmHg}$ were classified as hypertensive.

Plasma glucose, HDL, triglycerides and total cholesterol were measured by colorimetric enzymatic methods adapted for auto-analysis (Cobas $\mathrm{c} 111^{\mathrm{R}}$ analyser according to the glucose HK, HDL cholesterol Gen4, triglycerides and cholesterol Gen2 protocols of Roche diagnostics ${ }^{\mathrm{R}}$; Germany). Hyper-glycemia was defined as fasting plasma glucose $\geq 100 \mathrm{mg} / \mathrm{dL}$, hyper-triglycerides were defined as fasting plasma triglycerides $\geq 150 \mathrm{mg} / \mathrm{dL}$ and hyper-cholesterol was defined as total cholesterol $\geq$ $200 \mathrm{mg} / \mathrm{dL}$. The low-HDL group was defined as plasma $\mathrm{HDL}<40 \mathrm{mg} / \mathrm{dL}$ for men or plasma HDL $<50 \mathrm{mg} / \mathrm{dL}$ for women; otherwise, it was high-HDL. Smokers were defined as smoking at least one cigarette/day for 1 year in their lifetime; otherwise, they were considered as nonsmokers. Food intake data were collected based on subjects' food records for 3 days a week, 2 weekdays and 1 day at the weekend. All subjects were informed by a trained and experienced nutritionist how to record their food intake. Food record data were analysed with Nutri-survey software by a trained and experienced nutritionist.

\section{Genotyping}

Deoxyribonucleic acid (DNA) was extracted from the venous blood buffy-coat solid-phase using a proteinase K DNA extraction kit (FavorPrep ${ }^{\mathrm{R}}$ ). The purity and concentration were determined via the Nano-drop with a cut-off of $\sim 1.8$ for purity.

Polymerase chain reaction-restriction fragment length polymorphism (PCR-RFLP) analysis was performed for genotyping $[7,10]$, and products were visualised by electrophoresis at $100 \mathrm{~V}$ in a $3 \%$ agarose gel for $45 \mathrm{~min}$. The primers, digestion enzymes and digestion products for both genetic variants are shown in Table 1 . The PCR conditions were $94{ }^{\circ} \mathrm{C}$ for $7 \mathrm{~min}$ as initial denaturation and $1 \mathrm{~min}$ denaturation, followed by annealing at $60^{\circ} \mathrm{C}$

Table 1 PCR-RFLP primers, digestion enzymes and digestion products

\begin{tabular}{lll}
\hline Primer & $\begin{array}{l}\text { Digestion } \\
\text { enzyme }\end{array}$ & $\begin{array}{l}\text { Digestion } \\
\text { product }\end{array}$ \\
\hline rs4730153 & & \\
F:5'-AATTGGGTAAGGTATGGTTGA-3' & Rsal & $\begin{array}{l}\text { Gallele, } 100 \\
\text { and } 67 \text { bps } \\
\text { R:5'CAGATTAACTAGGCAGACACTTGA-3' }\end{array}$ \\
& A allele, 167 bps \\
\hline
\end{tabular}


for $1 \mathrm{~min}$ and extension at $72{ }^{\circ} \mathrm{C}$ for $1 \mathrm{~min}$, with a final extension of $7 \mathrm{~min}$.

\section{Data analysis}

The distribution of the continuous data scale was assessed by Kolmogorov-Smirnov and non-normally distributed data were log 10 transformed. Data not normally distributed after transformation are presented as median (minimal-maximum) and the Mann-Whitney test was used. Normally distributed data are presented as mean \pm standard deviation and the independent $t$-test was used for analysis. The association between the genetic variant and MetS and its diagnosed components was analysed by bivariate and multivariate analyses, with Pearson chi-square and Fisher tests used for bivariate analysis. Predictive logistic regression models were used for multivariate analysis adjusted for age, gender, obesity, hyper-cholesterol, smoking status and food intake data. The Hardy-Weinberg equilibrium (HWE) was tested.

\section{Results}

\section{Baseline sample characteristics}

The characteristics of the study participants are shown in Table 2. Gender proportion for case and control groups was similar, while the case subjects were older but this did not reach significance.

Waist circumference, BMI, blood pressure, plasma fasting glucose, triglycerides and total cholesterol were significantly higher in the MetS group than in the control group, whereas HDL plasma was significantly lower in the MetS group than in the controls. There were more smokers in the MetS group but this was not statistically insignificant.

The proportion of obese subjects was higher in the MetS group than in the control group $(86.7 \%[n=39]$ vs. $13.3 \%[n=6])$. Also, more subjects had hypercholesterol in the MetS group than in the control group $(71.4 \%[n=20]$ vs. $28.6 \%[n=8])$. Total calories, carbohydrates, fat and protein intake were higher in the MetS than in the control group but not statistically significant.

\section{Genotyping distribution}

The GG genotype of rs4730153 was the most frequent genotype, with the $\mathrm{G}$ allele being the wild type and the A allele was the minor allele. The minor allele frequency of rs 4730153 was $28 \%$ in this study population and the goodness of fit test showed deviation from the HWE (Table 3).

\section{Association of the genetic variant with MetS}

The association of MetS with the genetic variants was statistically insignificant with and without age stratification according to the bivariate analysis (Table 4). Since age stratification was based on the median age of the study subjects and for biological reasons, 45 years old was used as the cut-off point.

Bivariate analysis showed subjects with the GA, GG genotype and $\mathrm{G}$ allele of rs $4730153 \mathrm{had}$ a greater risk of MetS than the AA genotype in the age group $\leq 45$ years, while the recessive (GG/GA vs AA) and dominant (GG vs AA/GA) model showed a similar trend. Differences in the risk of genotypes were found in the age group $>45$ years, whereby the GA, GG and G allele carrier had a

Table 2 Baseline subject characteristics

\begin{tabular}{|c|c|c|c|}
\hline Characteristic & MetS $(n=84)$ & Control $(n=84)$ & $p$-value \\
\hline Age (years) & $46.15(22.06-65.7)$ & $45.66(20.46-65.85)$ & $1.000^{a}$ \\
\hline Sex (female), $n(\%)$ & $47(55.9)$ & $47(55.9)$ & $1.000^{c}$ \\
\hline BMI $\left(\mathrm{kg} / \mathrm{m}^{2}\right)$ & $29.9 \pm 4.71$ & $23.94 \pm 3.51$ & $<0.001^{\mathrm{a}}$ \\
\hline Waist circumference (cm) & $95.97 \pm 10.39$ & $81.04 \pm 8.8$ & $<0.001^{\mathrm{a}}$ \\
\hline Systolic blood pressure (mmHg) & $130(100-190)$ & $110(90-155)$ & $<0.001^{\mathrm{b}}$ \\
\hline Diastolic blood pressure (mmHg) & $85(60-145)$ & $75(60-95)$ & $<0.001^{b}$ \\
\hline Plasma fasting glucose (mg/dL) & $71.05(44.05-227.6)$ & $68.8(43.2-110.4)$ & $0.021^{b}$ \\
\hline Plasma fasting HDL (mg/dL) & $36.70 \pm 6.61$ & $43.22 \pm 10.05$ & $<0.001^{\mathrm{a}}$ \\
\hline Plasma fasting triglyceride (mg/dL) & $184.28 \pm 93.41$ & $101.57 \pm 41.62$ & $<0.001^{\mathrm{a}}$ \\
\hline Total cholesterol (mg/dL) & $184.1(88.1-380.2)$ & $159.3(95.3-250.2)$ & $<0.001^{\mathrm{b}}$ \\
\hline Smokers, n (\%) & $21(59.5)$ & $15(40.5)$ & $0.259^{c}$ \\
\hline Total calories (kcal) & $1203.3(803.4-2582.4)$ & 1178.5 (759.70-2014.4) & $0.503^{b}$ \\
\hline Carbohydrates (g) & $167.43 \pm 49.84$ & $164.44 \pm 46.79$ & $0.433^{\mathrm{a}}$ \\
\hline Fat (g) & $50.79 \pm 20.69$ & $46.70 \pm 16.30$ & $0.168^{a}$ \\
\hline Protein (g) & $44.40 \pm 14.94$ & $42.72 \pm 13.26$ & $0.433^{a}$ \\
\hline
\end{tabular}

${ }^{\mathrm{a}}$ Independent $t$-test, ${ }^{\mathrm{b}}$ Mann-Whitney test, ${ }^{\mathrm{C}}$ Pearson chi-square, $p<0.05$ 
Table 3 Genotype distribution of the genetic variance of NAMPT rs4730153

\begin{tabular}{|c|c|c|c|c|c|}
\hline Genotype & Observed value & Expected value & $X^{2}$ (DF) & $p$-value & MAF \\
\hline \multicolumn{6}{|l|}{ rs4730153 } \\
\hline AA & 24 & 13 & & & \\
\hline$A G$ & 47 & 68 & 16.17 & $3.1 \times 10^{-4}$ & 0.28 \\
\hline GG & 97 & 86 & & & \\
\hline
\end{tabular}

$X^{2}$ value with degrees of freedom $(D F)=2$. MAF minor allele frequency

lower odds ratio for MetS than the AA genotype. The association of genetic variance for rs4730153 and MetS was not statistically significant in both age groups (Table 4).

The multivariate analysis results are shown in Table 5 . Logistic regression analysis of the codominant, recessive and dominant genotype model and allele analysis was statistically significant with an odds ratio between 3.88 and 16.14. This model inserted obesity, hypercholesterolemia, smoking status, protein intake and fat intake as modifiers, which were selected based on $p>0.25$ in the bivariate analysis for age $\leq 45$ years.

\section{Discussion}

This study investigated the role of genetic variants of Visfatin rs4730153 as risk factors for MetS. The GG genotype, GG+GA genotype and $G$ allele carrier of rs4730153 were risk factors for MetS in interaction with modifying risk factors of obesity, hypercholesterolemia, smoking and food intake, especially in younger age in our population. Furthermore, our results confirm that MetS is multifactorial and that metabolic risk and food intake can modify genetic and MetS association.

A previous study reported that genetic variants of Visfatin rs4730153 played a role in the cardiometabolic risk in Segovia, Spain, with the GG genotype increases the risk for cardiovascular disease assessed with FRAMINGHAM and systematic coronary risk evaluation (SCORE) [8]. Both of these scores included blood pressure and HDL, metabolic risks that were also assessed in the NCEP-ATP III MetS diagnosis. Similarly, a study in China also reported obesity as a risk factor for MetS associated with the GG genotype [11]. Different genotype risks were reported in Han Chinese obese children, where the GG genotype was found to be a protective genotype against hyper-triglycerides [9]. Differences in the genotype risk between populations may be due to ethnicity, the criteria for subject recruitment or environmental factors.

The physiological mechanisms and how these genetic variants contribute to metabolic abnormalities remain unclear. However, an epidemiology study in Saudi Arabia found subjects with GG and GA genotypes had higher plasma Visfatin than the AA genotype [7], which supports the finding that GG genotype is a risk factor for diseases related to higher plasma Visfatin.

Higher plasma levels of Visfatin are associated with its role as a pro-inflammatory cytokine through the activated nuclear factor (NF) $\mathrm{kB}$ pathway. The upregulation of Visfatin promotes the release of other pro-inflammatory

Table 4 Association of the genetic variance of NAMPT rs4730153 with MetS stratified for age

\begin{tabular}{|c|c|c|c|c|c|c|c|c|}
\hline \multirow[t]{2}{*}{ rs4730153 } & \multicolumn{4}{|c|}{ Age $\leq 45$ years old } & \multicolumn{4}{|c|}{ Age $>45$ years old } \\
\hline & $\begin{array}{l}\text { MetS } \\
n=40\end{array}$ & $\begin{array}{l}\text { Control } \\
n=40\end{array}$ & $p$-value & OR $(95 \% \mathrm{Cl})$ & $\begin{array}{l}\text { MetS } \\
n=44\end{array}$ & $\begin{array}{l}\text { Control } \\
n=44\end{array}$ & $p$-value & OR $(95 \% \mathrm{Cl})$ \\
\hline \multicolumn{9}{|l|}{ Genotype } \\
\hline \multicolumn{9}{|c|}{ Additive model } \\
\hline AA & 3 & 7 & ref & & 9 & 5 & ref & \\
\hline GA & 9 & 11 & $0.350^{\mathrm{b}}$ & $1.91(0.38-9.6)$ & 13 & 14 & $0.326^{\mathrm{a}}$ & $0.516(0.14-1.9)$ \\
\hline GG & 28 & 22 & $0.124^{b}$ & $2.97(0.69-12.8)$ & 22 & 25 & $0.251^{\mathrm{a}}$ & $0.49(0.14-1.68)$ \\
\hline \multicolumn{9}{|c|}{ Recessive/dominant model } \\
\hline$A A$ & 3 & 7 & ref & & 9 & 5 & ref & \\
\hline $\mathrm{GG}+\mathrm{GA}$ & 37 & 33 & $0.176^{\mathrm{a}}$ & $2.61(0.63-10.95)$ & 35 & 39 & $0.244^{\mathrm{a}}$ & $0.500(0.15-1.63)$ \\
\hline $\mathrm{AA}+\mathrm{GA}$ & 12 & 18 & ref & & 22 & 29 & ref & \\
\hline GG & 28 & 22 & $0.166^{\mathrm{a}}$ & $1.91(0.76-4.79)$ & 22 & 25 & $0.521^{\mathrm{a}}$ & $0.76(0.33-1.76)$ \\
\hline A allele & 15 & 25 & ref & 1.97 & 31 & 24 & ref & 0.69 \\
\hline G allele & 65 & 55 & $0.068^{\mathrm{a}}$ & $(0.94-4.1)$ & 57 & 64 & $0.255^{a}$ & $(0.36-1.31)$ \\
\hline
\end{tabular}

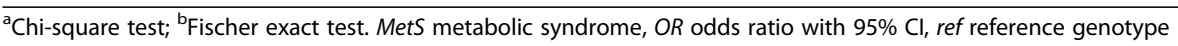


Table 5 Multivariate analysis of the association of the genetic variance of NAMPT rs4730153 with MetS and modifying factors for subjects aged $\leq 45$ years

\begin{tabular}{|c|c|c|c|c|}
\hline \multirow[t]{2}{*}{ rs4730153 for age $\leq 45$} & \multicolumn{4}{|c|}{ Logistic regression model } \\
\hline & $B$ & SE & $p$-value & Adjusted OR (95\% Cl) \\
\hline \multicolumn{5}{|l|}{ Genotype } \\
\hline \multicolumn{5}{|l|}{ Additive model } \\
\hline $\mathrm{AA}$ & & & ref & \\
\hline GA & & & NS & \\
\hline GG & 2.78 & 1.34 & 0.039 & $16.14(1.16-225.21)$ \\
\hline \multicolumn{5}{|c|}{ Recessive/dominant model } \\
\hline AA & & & ref & \\
\hline$G G+G A$ & 2.35 & 1.19 & 0.048 & $10.52(1.02-108.01)$ \\
\hline$A A+G A$ & & & ref & \\
\hline GG & 1.36 & 0.63 & 0.031 & $3.88(1.13-13.33)$ \\
\hline \multicolumn{5}{|l|}{ Allele } \\
\hline A allele & & & ref & 4.19 \\
\hline G allele & 1.43 & 0.52 & 0.006 & $(1.51-11.64)$ \\
\hline
\end{tabular}

Hosmer and Lemeshow test was performed to analyse the goodness of fit; $p$-value for all models was $>0.05$. Logistic regression model inserting obesity, hypercholesterolemia, smoking and food intake as modifiers. $B$ logistic regression model coefficient, NS non-significant, SE standard error, OR odds ratio with $95 \%$ $\mathrm{Cl}$, ref reference genotype

cytokines and has a role in the positive feedback of chronic inflammation, a component of MetS pathophysiology that can alter lipid metabolism, carbohydrate metabolism and adipocyte plasticity. Furthermore, it can lead to cardiometabolic abnormalities [12-16]. The NF-kB pathway induced by the increase in Visfatin increases the production of inducible nitrite oxide synthase (iNOS) which leads to endothelial dysfunction, which is also associated with cardiovascular risk, MetS and hypertension [17, 18].

Age stratification was performed in this study based on the Indonesian Health Ministry for determining age groups of adults, pre-elderly and elderly. Participants aged 22-45 years old (younger) were in the adult group, while subjects aged 46-66 years old (older) were in the pre-elderly and elderly groups. Differences in the metabolic profile related to ageing are influenced by hormones, body fat composition, metabolic rate and other environmental factors. These differences may also influence the genetic phenotype association $[19,20]$. Also, Visfatin plasma levels decline with age [21], which may temper the impact of NAMPT genetic variants on metabolic risk of phenotype in older age. The association of the NAMPT genetic variant was more prominent with metabolic risk in the younger group which was also found in a Chinese population as well as in our study $[9,11]$.

The minor allele frequency (MAF) of rs4730153 (0.28) in this study was higher than other studies conducted in Asia (0.08-0.11) but lower than studies in Europe (0.42) or South America $(0.50)$ [8, 10, 11, 22]. The G allele was reported as wild type, which was the same for all studies.
The deviation from HWE in our population may be related to the small sample size. Other studies also reported a deviation of HWE in the NAMPT genetic variant in their populations $[10,23]$. We performed PCR-RFLP for genotyping, an established, reliable and affordable method for genotyping, especially when resources are limited [24, 25].

This case-control pilot study of a Javanese, especially those who lived in the Yogyakarta region, although small, the number of participants met minimal quota sampling which was calculated based on the hypothesis for an odds ratio for a case-control study. Two large epidemiology studies reported that the prevalence of MetS in Indonesia varies from 21.66 to $39.0 \%$ [26, 27]. The study which reported a comparison of the prevalence of MetS among ethnic groups and regions in Indonesia reported a prevalence of MetS in Yogyakarta of $15.4 \%$ and the Javanese of $19.85 \%$, lower than the national prevalence [27]. This difference may influence the age of the study participants, time of surveillance performed and methods for diagnosis of MetS component. The laboratory measurement of the two studies used capillary blood but did not mention if the blood sample was fasting and one study did not measure triglycerides [26, 27]. Capillary blood for the measurement of blood glucose and cholesterol is more affordable for large surveillance but not the gold standard for blood glucose, cholesterol and triglycerides. Our study used plasma from the peripheral blood vein collected after $8-10 \mathrm{~h}$ of fasting, which is the gold standard for measurement of the metabolite profile. 
To the best of our knowledge, this is the first study of the Javanese population who live in Yogyakarta, Indonesia, that reported genetic variants of the NAMPT gene are associated with MetS. However, MetS is a multifactorial disease, with polygenic interactions other than the NAMPT gene, epigenetic regulation, other lifestyle and environmental factors contribute to the pathophysiology. The case and control groups were carefully age- and sex-matched and dietary intake was recorded to reduce research bias. Some limitations of our study were the small sample size and the lack of measurement of plasma Visfatin and physical activities.

\section{Conclusion}

The GG, GA+GG genotype and G allele carrier of NAMPT rs4730153 have a higher risk for suffering MetS in our study population, interacting with other metabolic risks, smoking and food intake, especially in younger age groups. Further larger, multicentre and multifactorial (genetic and non-genetic) studies are required to confirm these results.

\section{Abbreviations}

BMI: Body mass index; DNA: Deoxyribonucleic acid; HDL: High-density lipoprotein; HWE: Hardy-Weinberg equilibrium; iNOS: Nitrite oxide synthase; MAF: Minor allele frequency; MetS: Metabolic syndrome; NAMP

T: Nicotinamide phosphoribosyltransferase; NCEP-ATP: National Cholesterol Education Program-Adult Panel Treatment; NF: Nuclear factor; PCRRFLP: Polymerase chain reaction-restriction fragment length polymorphism; SNP: Single nucleotide polymorphism; SCORE: Systematic coronary risk evaluation; WAT: White adipose tissue

\section{Acknowledgements}

We thank all the biochemistry and clinical pathology technicians for helping in metabolite and genotyping measurements. We also extend our thanks to the Faculty of Medicine, Public Health and Nursing, Universitas Gadjah Mada, for supporting this research through "Dana Masyarakat and Rekognisi Tugas Akhir" research grant.

\section{Authors' contributions}

All authors contributed to this research. AP, RM and CM were involved in collecting the participant data, sample and laboratory analysis. AP, IS, PH and AHM performed and interpreted the data and manuscript editing. All authors read and approved the final manuscript.

\section{Funding}

This research had partially been funded by Universitas Gadjah Mada in Grant "Program Rekognisi Tugas Akhir Tahun 2019". This grant recipient is Mrs. Pramudji Hastuti. The funder role was supporting fund for this research especially for sample collecting and genotyping.

\section{Availability of data and materials}

The data sets analysed during the current study are not publicly available due to subject confidential agreement but are available from the corresponding author on reasonable request.

\section{Declarations}

\section{Ethics approval and consent to participate}

The study protocol was arranged based on the Helsinki Declaration and had approval from the Medical and Health Research Ethics Committee of the Faculty of Medicine, Public Health and Nursing, Universitas Gadjah Mada, Dr. Sardjito Public Hospital, Yogyakarta, Indonesia. Ethical approval number was KE/0621/05/2018. All subjects who participated signed informed consent forms after receiving detailed information concerning the purpose of the study.
Consent for publication

Not applicable

\section{Competing interests}

The authors declare that they have no competing interests.

\section{Author details}

${ }^{1}$ Department of Biochemistry, Faculty of Medicine, Public Health and Nursing, Universitas Gadjah Mada, Yogyakarta, Indonesia. ${ }^{2}$ Department of Medical Biology and Biochemistry, Faculty of Medicine and Health Sciences, Universitas Jambi, Jambi, Indonesia. ${ }^{3}$ Diploma Degree Technology of Medical Laboratory, Faculty of Health Technology, Universitas Mega Rezky, Makassar, Indonesia. ${ }^{4}$ Department of Biochemistry, Faculty of Medicine and Health Sciences, Universitas Muhammadiyah Yogyakarta, Yogyakarta, Indonesia.

Received: 9 February 2021 Accepted: 3 August 2021

Published online: 11 August 2021

\section{References}

1. Ranasinghe $P$, Mathangasinghe $Y$, Jayawardena R, Hills AP, Misra A (2017) Prevalence and trends of metabolic syndrome among adults in the AsiaPacific region: a systematic review. BMC Public Health 17(1):101. https://doi. org/10.1186/s12889-017-4041-1

2. Huang PL (2009) A comprehensive definition for metabolic syndrome. Dis Model Mech 2(5-6):231-237. https://doi.org/10.1242/dmm.001180

3. Galassi A, Reynolds K, He J (2006) Metabolic syndrome and risk of cardiovascular disease: a meta-analysis. Am J Med 119(10):812-819. https:// doi.org/10.1016/j.amjmed.2006.02.031

4. Musani SK, Martin LJ, Woo JG, Olivier M, Gurka MJ, Deboer MD (2017) Heritability of the severity of the metabolic syndrome in whites and blacks in 3 large cohorts. Circ Cardiovasc Genet 10(2):e001621. https://doi.org/10.11 61/circgenetics.116.001621

5. Garten A, Schuster S, Penke M, Gorski T, de Giorgis T, Kiess W (2015) Physiological and pathophysiological roles of NAMPT and NAD metabolism. Nat Rev Endocrinol 11(9):535-546. https://doi.org/10.1038/nrendo.2015.117

6. Chang YH, Chang DM, Lin KC, Shin SJ, Lee YJ (2011) Visfatin in overweight/ obesity, type 2 diabetes mellitus, insulin resistance, metabolic syndrome and cardiovascular diseases: a meta-analysis and systemic review. Diabetes Metab Res Rev 27(6):515-527. https://doi.org/10.1002/dmrr.1201

7. Al-Harithy RN (2014) Common polymorphisms in the NAMPT gene (NAMPT/ PBEF1) influence Visfatin-circulating levels in a Saudi population. Life Sci 11(10):205-210

8. Martinez Larrad MT, Corbaton Anchuelo A, Fernandez Perez C, Perez Barba M, Lazcano Redondo Y, Serrano RM (2016) Obesity and cardiovascular risk: variations in NAMPT gene can modify the obesity associated cardiovascular risk. Results from the Segovia population based-study Spain. PLoS ONE 11(5):e0153976. https://doi.org/10.1371/journal.pone.0153976

9. Lai A, Chen W, Helm K (2013) Effects of NAMPT gene polymorphism rs4730153 on exercise-induced weight loss of obese children and adolescents of Han Chinese. Int J Biol Sci 9(1):16-21. https://doi.org/10.7150/ ijbs.4918

10. Dou Q, Peng Y, Zhou B, Zhang K, Lin J, Dai X, Zhang L, Rao L (2015) Association of nicotinamide phosphoribosyltransferase (NAMPT) gene polymorphisms and serum NAMPT levels with dilated cardiomyopathy in a Chinese population. Int J Mol Sci 16(9):22299-22318. https://doi.org/10.33 90/ijms160922299

11. Rong J, Chu M, Xing B, Zhu L, Wang S, Tao T (2015) Variation in the PBEF gene are associated with body mass index: a population-based study in northern China. Meta Gene 6:65-68. https://doi.org/10.1016/j.mgene.2015. 08.004

12. Hector J, Schwarzloh B, Goehring J, Strate TG, Hess UF, Deuretzbacher G, Hansen-Algenstaedt N, Beil FU, Algenstaedt P (2007) TNF-a alters Visfatin and adiponectin levels in human fat. Horm Metab Res 39(4):250-255. https://doi.org/10.1055/s-2007-973075

13. Moschen AR, Gerner RR, Tilg H (2010) Pre-B cell colony enhancing factor/ NAMPTNisfatin in inflammation and obesity-related disorders. Curr Pharm Des 16(17):1913-1920. https://doi.org/10.2174/138161210791208947

14. Sommer G, Kralisch S, Kloting N, Kamprad M, Schrock K, Kratzsch J, Tonjes A Lossner U, Bluher M, Stumvoll M, Fasshauer M (2010) Visfatin is a positive reglukosator of MCP-1 in human adipocytes in vitro and in mice in vivo. Obesity. 18(8):1486-1492. https://doi.org/10.1038/oby.2009.462 
15. Friebe $D$, Loffler $D$, Schonberg $M$, Bernhard F, Buttner $P$, Landgraf $K$ et al (2011) Impact of metabolic regulators on the expression of the obesityassociated genes FTO and NAMPT in human preadipocytes and adipocytes. PLOS ONE 6(6):e19526. https://doi.org/10.1371/journal.pone.0019526

16. Kim HS, Han SY, Sung HY, Park SH, Kang MK, Han SJ, Kang YH (2014) Blockade of Visfatin induction by oleanolic acid via disturbing IL-6-TRAF6NF- i B signaling of adipocytes. Exp Biol Med 239(3):284-292. https://doi. org/10.1177/1535370213514511

17. Romacho T, Azcutia V, Vazquez-Bella M, Matesanz N, Cercas E, Nevado J et al (2009) Extracellular PBEF/NAMPTNisfatin activates pro-inflammatory signalling in human vascular smooth muscle cells through nicotinamide phosphoribosyltransferase activity. Diabetologia. 52(11):2455-2463. https:/ doi.org/10.1007/s00125-009-1509-2

18. Dahl TB, Bermudez B, Ranheim T, Otterdal K, Holm S, Al-Biessen E, Halvorsen B et al (2012) Unraveling the role of nicotinamide phosphoribosyltransferase on lipids in atherosclerosis. Clin Lipidol 7(6):697-707. https://doi.org/10.221 $7 / c \mid p .12 .71$

19. Ziaei S, Mohseni H (2013) Correlation between hormonal statuses and metabolic syndrome in postmenopausal women. J Family Reprod Health 7(2):63-66

20. St-Onge M, Gallagher D (2010) Body composition change with aging: the cause or the result of alteration in metabolic rate and macronutrient oxidation? Nutrition. 26(2):152-155. https://doi.org/10.1016/j.nut.2009.07.004

21. de Luis DA, Gonzales Sagrado M, Conde R, Aller R, Izaola O, Romero E (2008) Effect of a hypocaloric diet on serum Visfatin in obese non-diabetic patients. Nutrition. 24(6):517-521. https://doi.org/10.1016/.jnut.2008.01.052

22. Ferrari DF, Rodrigues JAL, Fernandes IA, Bueno Junior CR (2016) Association between rs4730153 gene SNP and fasting glucose, triglyceride, HDL and body mass index levels in overweight Brazilian adults. Int J Cardiovasc Sci 29(6):471-476. https://doi.org/10.5935/2359-4802.20160067

23. Vasilache SL, Mărginean CO, Boaghi A, Pop RM, Banescu C, Moldovan VG, Hutanu A, Duicu C, Pascanu IM (2020) Implications of Visfatin genetic variants in the metabolic profile of the Romanian pediatric population. Rev Romana Med Lab 28(2):163-174. https://doi.org/10.2478/rrlm-2020-0015

24. Gunadi, Dwihantoro A, Iskandar K, Makhmudi A, Rochadi (2016) Accuracy of polymerase chain reaction-restriction fragment length polymorphism for RET rs2435357 genotyping as Hirschsprung risk. J Surg Res 203(1):91-94. https://doi.org/10.1016/j.jss.2016.02.039 Epub 2016 Mar 5

25. Hubáček JA, Pikhart H, Peasey A, Kubínová R, Bobák M (2015) Nobody is perfect: comparison of the accuracy of PCR-RFLP and KASPTM method fo genotyping. ADH1B and FTO polymorphisms as examples. Folia Biol (Praha) 61(4):156-160

26. Sigit FS, Tahapary DL, Trompet S, Sartono E, Willems van Dijk K, Rosendaal FR, de Mutsert R (2020) The prevalence of metabolic syndrome and its association with body fat distribution in middle-aged individuals from Indonesia and the Netherlands: a cross-sectional analysis of two populationbased studies. Diabetol Metab Syndr 12(1):2. https://doi.org/10.1186/s13098019-0503-1

27. Herningtyas EH, Ng TS (2019) Prevalence and distribution of metabolic syndrome and its components among provinces and ethnic groups in Indonesia. BMC Public Health 19(1):377. https://doi.org/10.1186/s12889-0196711-7

\section{Publisher's Note}

Springer Nature remains neutral with regard to jurisdictional claims in published maps and institutional affiliations.

\section{Submit your manuscript to a SpringerOpen ${ }^{\circ}$ journal and benefit from:}

- Convenient online submission

- Rigorous peer review

- Open access: articles freely available online

- High visibility within the field

- Retaining the copyright to your article

Submit your next manuscript at $\boldsymbol{\nabla}$ springeropen.com 